\title{
KEMAMPUAN LOMPAT JAUH MENGGUNAKAN MEDIA "KB" KELAS V SDN 11 DURIAN SEBATANG
}

\author{
Udin Joharuddin \\ Guru SDN 11 Durian Sebatang \\ Email: udinjoharuddinsdn11duriansebatang@gmail.com
}

\begin{abstract}
Sports activity for grade V elementary school students is not an abstract experience. Therefore, the use of used cardboard props is very important to make it easier for students to learn the long jump practice. One of the alternative props that can be used in the long jump practice is used cardboard (KB). The purpose of this research is to find out that the use of used cardboard props $(K B)$ can improve the long jump ability of grade V students of SDN 11 Durian Sebatang, Seponti District, Kayong Utara Regency. After carrying out Classroom Action Research for 2 cycles, in general it can be said that by using used cardboard props (KB) students' long jump abilities were quantitatively increased. In addition, the interest, attention, participation and presentation of students also increased.
\end{abstract}

Keywords: Ability, Long Jump, Media "KB"

\begin{abstract}
Abstrak
Aktifitas olahraga bagi peserta didik kelas $\mathrm{V}$ sekolah dasar bukanlah merupakan pengalaman yang bersifat abstrak. Oleh karena itu penggunaan alat peraga kardus bekas yang tepat sangat penting dilakukan untuk memudahkan peserta didik dalam mempelajari praktek lompat jauh. Salah satu alternatif alat peraga yang bisa digunakan dalam praktek lompat jauh adalah Kardus Bekas (KB). Adapun tujuan dari penelitian ini adalah Untuk mengatahui penggunaan alat peraga Kardus Bekas (KB) dapat meningkatkan kemampuan Lompat Jauh pada peserta didik kelas V SDN 11 Durian Sebatang Kecamatan Seponti Kabupaten Kayong Utara. Setelah dilaksanakan penelitian tindakan Kelas selama 2 Siklus Penelitian secara umum dapat dikatakan bahwa dengan menggunakan alat peraga Kardus Bekas (KB) kemampuan peserta didik secara kuantitatif dalam bentuk kemampuan lompat jauh dan secara kualitatif dalam bentuk minat, perhatian, partisipasi dan presentasi peserta didik lebih meningkat.
\end{abstract}

\section{Kata Kunci: Kemampuan, Lompat Jauh, Media "KB"}

\section{PENDAHULUAN}

Pendidikan Jasmani diganti dengan istilah pedagogi olahraga dengan model teori Haag, maka suatu ketika (di Surabaya) para pakar Pendidikan Jasmani Indonesia menetapkan bahwa istilahi Pendidikan Jasmani diganti dengan istilah pedaogi olahraga. Namun, T. Cholik Mutohir (1997), mengatakan bahwa, penggunaan istilah pedaogi olahraga bukan merupakan hal yang baru, akan tetapi istilah tersebut hanya memperluas pelaksanaan dan tujuan Pendidikan Jasmani. Pada umumnya para pakar di Negaranegara Eropa lebih banyak menggunakan istilah pedagogy, sedangkan di Amrerika (khususnya di Amerika serikat), mereka lebih suka menggunakan istilah education. Dan berkaitan dengan istilah terakhir ini digunakan juga istilah instructional, yang berarti 'pengajaran.'

Sosialisasi istilah baru beserta peleksanaanya, menurut hemat penulis, sebaiknya segera dilaksanakan. Meskipun beberapa perguruan tinggi telah menggunakan istilah baru (sport education) tersebut, namun belum juga ada petunjuk pelaksanaan sehingga belum dapat diketahui di mana letak perbedaannya dengan pelaksanaan Pendidikan Jasmani mungkin kalau diberi penjelasan secara gamlang, pendidikan jasmani itu lebih berdasar pada pengenalan mengenai cabang olahraga sedangkan olahraga itu terfokus untuk pembinaan dalam mencapai prestasi dalam kompetisi keolahrgaan.

Dari uraian pada halaman sebelumnya dapat ditarik suatu pandagan bahwa antara olahraga dan pendidikan jasmani itu sendiri merupakan suatu hubungan yang sangat signifikan atau berkesinambungan, hanya karena perbedaan dari bahasa dan pemaknaan, yakni untuk olahraga lebih difokuskan untuk peningkatan prestasi dalam cabang olahraga sedangkan untuk pendidikan jasmani tidak difokuskan untuk 
prestasi tapi lebih mengarah kepada ilmu tentang olahraga.

Salah satu konsep dasar dalam pelajaran penjaskes adalah kemampuan bergerak (jasmani). Pelajaran Penjaskes khususnya dalam hal melakukan aktifitas jasmani merupakan pelajaran yang dianggap melelahkan bagi banyak anak. Meskipun demikian peserta didik tersebut wajib untuk menguasai mata pelajaran tersebut karena merupakan kebutuhan untuk memecahkan masalah kehidupan sehari-hari. Banyak faktor yang menyebabkan pelajaran penjaskes menjadi pelajaran yang dihindari oleh peserta didik. Salah satunya adalah penjaskes membutuhkan kemampuan fisik yang mapan. Banyak peserta didik yang merasa terbebani dengan pelajaran penjaskse karena dibutuhkan kemampuan jasmani dalam mempelajari hal tersebut.

Untuk mempelajari penjaskses maka tugas guru adalah menyajikan mata pelajaran tersebut dalam situasi yang menyenangkan dan tidak membosankan bagi peserta didik. Selain itu dipahami bahwa peserta didik kelas tinggi khususnya kelas V sekolah dasar.

Untuk menghadirkan pengalaman konkrit dalam bentuk nyata khususnya dalam pelajaran Penjaskes konsep ataupun praktek (pengelolaan jasmani), maka seorang guru hendaknya menggunakan media/ alat peraga sehingga pengalaman belajar yang dimiliki oleh peserta didik benar-benar nyata dan tersimpan dengan baik dalam pemahaman peserta didik.

Aktifitas olahraga bagi peserta didik kelas $\mathrm{V}$ sekolah dasar bukanlah merupakan pengalaman yang bersifat abstrak. Oleh karena itu penggunaan alat peraga kardus bekas yang tepat sangat penting dilakukan untuk memudahkan peserta didik dalam mempelajari praktek lompat jauh. Salah satu alternatif alat peraga yang bisa digunakan dalam praktek lompat jauh adalah Kardus Bekas (KB).

Adapun tujuan dari penelitian ini adalah Untuk mengatahui penggunaan alat peraga Kardus Bekas (KB) dapat meningkatkan kemampuan Lompat Jauh pada peserta didik kelas V SDN 11 Durian Sebatang Kecamatan Seponti Kabupaten Kayong Utara.

Kegiatan Belajar Mengajar (KBM) yang dilaksanakan setiap hari, merupakan kehidupan dari suatu kelas, dimana guru dan peserta didik saling terkait dalam pelaksanaan kegiatan yang telah direncanakan oleh guru. Keberhasilan kegiatan tersebut sepenuhnya menjadi tanggung jawab guru, karena guru merupakan pengelola tunggal di dalam kelas. Oleh karena itu bila peserta didik kurang bisa menunjukan keterampilan dalam suatu mata pelajaran, maka tuduhan kekurang berhasilan juga tertuju kepada guru.
Berdasar hal-hal tersebut di atas dapatlah ditarik suatu kesimpulan bahwa dalam belajar penjaskes, pengalaman belajar anak sangatlah penting. Pengalaman tersebut akan membentuk suatu pemahaman apabila ditunjang dengan alat bantu belajar, yang berfungsi mengkonkretkan materi-materi Penjaskes yang bersifat abstrak. Dengan demikian alat bantu belajar atau biasa disebut media akan berfungsi dengan baik apabila media tersebut dapat memberikan pengalaman belajar yang bermakna, mengaktifkan dan menyenangkan anak. Dapat dikatakan bahwa media pembelajaran penjaskes memiliki peranan sangat besar bagi guru yaitu untuk menyampaikan konsep-konsep dasar penjaskes maupun bagi peserta didik dalam menerima pengetahuan yang disampaikan guru kepadanya. Suatu fakta yang patut direnungkan dan disadari sepenuhnya untuk dilakukan tindak lanjut secara nyata bagi semuanya yang terlibat di dunia pendidikan bahwa: pengajaran penjaskes SD menggunakan alat peraga dan media lainnya secara tepat dibandingkan dengan yang tanpa menggunakan adalah enam berbanding satu atau $6: 1$. Jadi penggunaan alat peraga dan media lainnya dalam pembelajaran penjaskes (khususnya dalam memberikan penanaman konsep) akan membawa hasil enam kali lebih baik dan lebih cepat dibandingkan dengan pengajaran drill tanpa konsep.

Dengan menggunakan keterampilan masingmasing mereka dapat menyelidiki atau mengamati benda-benda di sekitarnya, kemudian mengorganisirnya untuk memecahkan suatu masalah. (2) Memberikan motivasi dan memudahkan abstraksi. Dengan alat peraga diharapkan peserta didik lebih memperoleh pengalaman-pengalaman yang baru dan menyenangkan, sehingga mereka dapat menghubungkannya dengan matematika yang bersifat abstrak.

Bila kita cermati pembelajaran yang terjadi di sekolah saat ini, masih banyak yang dikelola secara klasikal. Artinya semua peserta didik diperlakukan sama oleh guru. Pembelajaran klasikal merupakan pembelajaran yang paling disenangi oleh guru karena cara ini mudah dilaksanakan. Pada pembelajaran klasikal umumnya komunikasi terjadi searah, yaitu dari guru ke peserta didik, dan hampir tidak terjadi sebaliknya. Oleh sebab itu penggunaan alat peraganya didominasi oleh guru. Pada umumnya hanya sebagaian kecil dari peserta didik yang dapat memanfaatkan alat peraga tersebut. Untuk meminimalisasi dominasi guru dalam penggunaan alat peraga, maka perlu direncanakan dan dikembangkan alat peraga untuk kelompok atau individu. Ada beberapa keuntungan bila alat peraga digunakan untuk kelompok, antara lain: 
(1) adanya tutor sebaya dalam kelompok, akan dapat membantu guru dalam menerangkan pemanfaatan alat peraga kepada temannya, (2) Kerjasama yang terjadi dalam penggunaan alat peraga kelompok akan membuat suasana kelas lebih menyenangkan, (3) Banyaknya anggota kelompok yang relatif kecil akan memudahkan peserta didik untuk berdiskusi dan bekerjasama dalam pemanfaatan alat.

Selain mempersiapkan langkah-langkah penggunaan alat peraga, seperti persiapan guru, lingkungan, persiapan peserta didik, maka perlu pula mengetahui prinsip-prinsip umum dalam penggunaan alat peraga, di antaranya sebagai berikut. (1) Penggunaan alat peraga hendaknya sesuai dengan tujuan pembelajaran. (2) Alat peraga yang digunakan hendaknya sesuai dengan metode/strategi pembelajaran. (3) Tidak ada satu alat peragapun yang dapat atau sesuai untuk segala macam kegiatan belajar. (4) Guru harus terampil menggunakan alat peraga dalam pembelajaran. (5) Peraga yang digunakan harus sesuai dengan kemampuan peserta didik dan gaya belajarnya. (6) Pemilihan alat peraga harus obyektif, tidak didasarkan kepada kesenangan pribadi. (7) Keberhasilan penggunaan alat peraga juga dipengaruhi oleh kondisi lingkungan.

Ada beberapa persyaratan yang harus dimiliki alat peraga agar fungsi atau manfaat dari alat peraga tersebut sesuai dengan yang diharapkan dalam pembelajaran. (1) Sesuai dengan konsep penjaskes. (2) Dapat memperjelas konsep penjaskes, baik dalam bentuk real, gambar atau diagram dan bukan sebaliknya (mempersulit pemahaman konsep penjaskes). (3) Tahan lama (dibuat dari bahan-bahan yang cukup kuat). (4) Bentuk dan warnanya menarik. (5) Dari bahan yang aman bagi kesehatan peserta didik. (6) Sederhana dan mudah dikelola. (7) Ukuran sesuai atau seimbang dengan ukuran fisik dari peserta didik. (8) Peragan diharapkan menjadi dasar bagi tumbuhnya konsep berpikir abstrak bagi peserta didik, karena alat peraga tersebut dapat dimanipulasi (dapat diraba, dipegang, dipindahkan, dipasangkan, dan sebagainya) agar peserta didik dapat belajar secara aktif baik secara individual maupun kelompok. (9) Bila mungkin alat peraga tersebut dapat berfaedah banyak.

Pemilihan alat peraga yang tepat dan digunakan secara benar diharapkan dapat: (1) Mempermudah abstraksi, (2) Memudahkan, memperbaiki, atau meningkatkan penguasaan konsep atau fakta, (3) Memberikan motivasi, (4) Memberikan variasi pembelajaran, (5) Meningkatkan efisiensi waktu, (6) Menunjang kegiatan matematika di luar kelas yang menunjukkan penerapan matematika pada peristiwa nyata, dan (7) Meningkatkan keterlibatan peserta didik dalam pembelajaran.
Penggunakan alat peraga tidak selamanya membuahkan hasil belajar yang lebih meningkat, lebih menarik, dan sebagainya. Adakalanya menyebabkan hal yang sebaliknya, yaitu menyebabkan kegagalan peserta didik dalam belajar. Kegagalan itu akan nampak bila: (1) Generalisasi konsep abstrak dari representasi halhal yang konkret tidak tercapai, (2) Alat peraga yang digunakan hanya sekedar sajian yang tidak memiliki nilai-nilai yang tidak menunjang konsep-konsep dalam matematika, (3) Tidak disajikan pada saat yang tepat, (4) Memboroskan waktu, (5) Diberikan pada anak yang sebenarnya tidak memerlukannya, dan (6) Tidak menarik dan mempersulit konsep yang dipelajari.

Kegiatan idenifikasi kebutuhan alat peraga yang digunakan di SD dari kelas I sampai dengan kelas VI merupakan kegiatan yang seharusnya dilakukan oleh guru pengampu kelas yang bersangkutan baik secara individu atau kelompok ditingkat sekolah maupun tingkat KKG. Kegiatan ini memerlukan ketekunan dan inovasi dari guru sehingga dapat menentukan dan mengembangkan alat peraga yang digunakan berdasar pada kurikulum yang berlaku. Pencermatan terhadap kurikulum mengenai indikator, hasil belajar dan materi akan menentukan alat peraga yang dapat digunakan atau dikembangkan.

Kardus Bekas (KB) merupakan alat peraga yang diciptakan oleh kelompok peneliti dengan memanfaatkan bahan-bahan yang ada di sekitar yaitu dari kardus yang sudah tidak digunakan. Untuk lebih jelas dapat dilihat pada gambar di bawah ini.

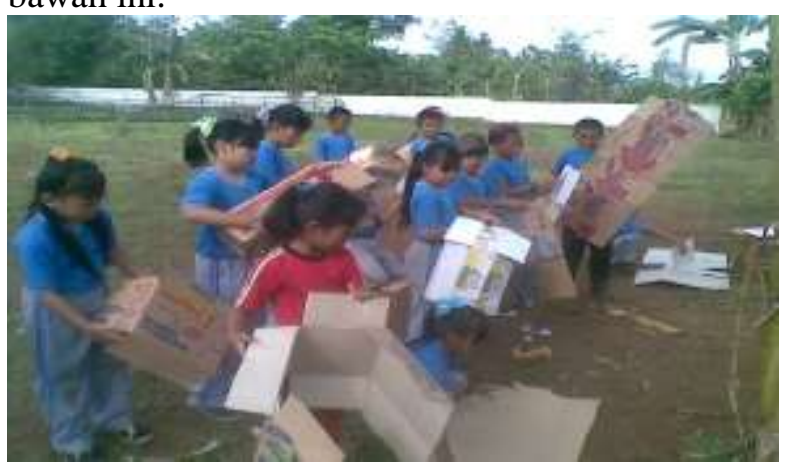

Gambar 1. Alat Peraga KB yang Akan Digunakan Peserta Didik

Kardus Bekas (KB) dikumpulkan dengan berbagai macam kardus bekas untumenarik perhatian peserta didik. Pada setiap kardus bekas diberi kebebasan pada peserta didik untuk mengumpulka sesuai ketersediaan yang ada bagi peserta didik dalam melakukan aktivitas dengan menggunakan alat ini. Penggunaan alat peraga KB ini dilakukan dengan menggunakan 2 kaki yaitu untuk tempat pendaratan peserta didik pada saat melakukan pendaratan. 


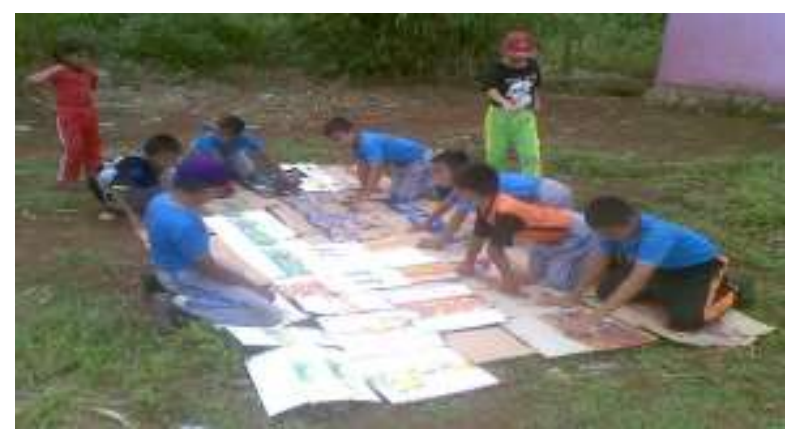

Gambar 2. Menyusun Kardus Bekas Diatas Lintasan Lompat Jauh

Kemudian peserta didik, melakukan kegiatan lompatan dengan terlebih dahulu melakukan sikap awalan pada lintasan yang jaraknya kurang lebih 45 meter.

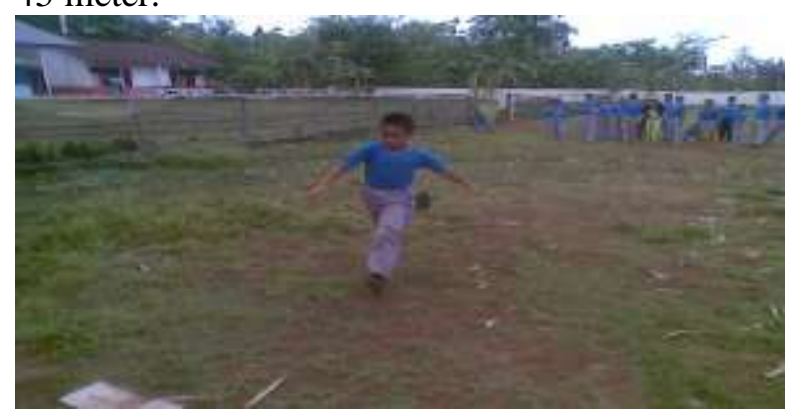

Gambar 3. Awalan Lompat Jauh

Setelah itu peserta didik akan berlari dengan kaidah lari sesuai aturan yang berlaku sembari bersiap-siap melakukan tolakan atau tumpuan, setelah melakukan tolakan/tumpuan peserta didik akan melakukan lompatan setalah melakukan lompatan peserta didik akan melakukan pendaratan.

Keunggulan dari alat peraga ini adalah selain mudah dibuat, juga sebagai alat peraga yang dirasakan dan dilakukan langsung oleh peserta didik sehingga secara konkrit peserta didik melakukan kegiatan lompatan dengan tidak raguragu dan takut. Kegiatan lompat jauh yang dilakukan oleh peserta didik memungkinkan peserta didik memperoleh pembelajaran yang menyenangkan dan bermakna sehingga dengan mudah peserta didik akan memperoleh pemahaman yang lebih. Selain itu adanya aktifitas penggunaan KB bertujuan untuk mengurangi tingkat cedera pada peserta didik pada saat melakukan aktivitas lompat jauh.

\section{METODE PENELITIAN}

Penelitian ini adalah penelitian tindakan kelas (Classroom action research) dengan tahapantahapan pelaksanaan meliputi; perencanaan, pelaksanaan tindakan, observasi dan evaluasi, dan refleksi. Penelitian ini dilaksanakan di SDN 11 Durian Sebatang Kecamatan Sukadana Kabupaten Kayong Utara. Yang menjadi subjek dalam penelitian tindakan kelas ini adalah peserta didik kelas V SDN 11 Durian Sebatang Kecamatan Sukadana Kabupaten Kayong Utara pada semester ganjil tahun pelajaran 2019/2020.

Ada beberapa faktor yang diselidiki dalam penelitian ini. Faktor-faktor tersebut adalah sebagai berikut: (1) Faktor peserta didik, yaitu dengan melihat kesiapan, kesungguhan, dan keaktifan peserta didik dalam menerima dan mengikuti pelajaran serta sejauh mana peserta didik mampu melakukan lompat jauh dengan menggunakan alat peraga kardus Bekas (KB). (2) Faktor guru, yaitu dengan melihat bagaimana materi pelajaran dipersiapkan serta bagaimana menggunakan alat peraga KB dalam materi yang diajarkan. (3) Faktor hasil, yaitu dengan melihat hasil belajar peserta didik yang diperoleh dari tes akhir pada siklus.

Penelitian ini dilaksanakan dengan dua siklus. Siklus pertama dan kedua masing-masing berlangsung dua minggu (4 kali pertemuan) yang terdiri dari 2 Siklus yang masing-masing siklus terdiri dari tahap perencanaan, pelaksanaan, observasi dan refleksi.

Sumber data, sumber data penelitian ini adalah dari peserta didik dan guru. Jenis data, jenis data yang didapatkan dalam penelitian ini adalah data kuantitatif yang terdiri dari tes hasil belajar dan data dari lembar observasi. (1) Data hasil belajar peserta didik diperoleh dari tes yang diberikan kepada peserta didik. (2) Data tentang situasi belajar mengajar diambil pada saat dilaksanakannya penelitian dengan menggunakan lembar observasi. Data yang diperoleh dalam penelitian ini selanjutnya akan dianalisis secara kuantitatif dan kualitatif. Untuk analisis kuantitatif digunakan statistik deskriptif untuk mendeskripsikan karateristik responden. Untuk analisis kulitatif digunakan kategorisasi. Kriteria yang digunakan untuk menentukan kategori skor penguasaan mata pelajaran Penjaskes adalah teknik kategorisasi Standar berdasarkan Tetapan Departemen Pendidikan Nasional dalam Sri Satriani (2005: 25) yaitu: (1) Untuk tingkat penguasaan $0 \%-34 \%$ dikategorikan sangat rendah. (2) Untuk tingkat penguasaan $35 \%$ - 54 $\%$ dikategorikan rendah. (3) Untuk tingkat penguasaan $55 \%$ - $64 \%$ dikategorikan sedang. (4) Untuk tingkat penguasaan $65 \%-84 \%$ dikategorikan tinggi. (5) Untuk tingkat penguasaan $85 \%$ - $100 \%$ dikategorikan sangat tinggi.

\section{HASIL DAN PEMBAHASAN Hasil}

Penelitian ini dilakukan selama proses belajar mengajar dalam bulan Agustus sampai November 2019, tepatnya tanggal 14 Agustus sampai 14 November 2019 (Tahap perencanaan sampai laporan) yang dibagi menjadi dua siklus dimana 
setiap siklus dilakukan sebanyak 2 kali pertemuan.

\section{Siklus I}

Pelaksanaan Tindakan. Sesuai dengan rencana yang disiapkan (lampiran RPP) yaitu kegiatan pembelajaran yang menggunakan pendekatan tematik diawali dengan kegiatan berbaris sebagai kegiatan untuk membuka dan menciptakan suasana pembelajaran yang lebih baik. Setelah peserta didik berbaris selanjutnya guru membagi peserta didik menjadi beberapa kelompok. Setelah peserta didik dibagi menjadi kelompok langkah selanjutnya adalah menjelaskan kepada peserta didik tata cara penggunaan alat peraga "KB" dan peserta didik diminta untuk memperhatikan.

Setelah peserta didik mengetahui tata cara penggunaan alat peraga, guru meminta perwakilan kelompok untuk menggunakan alat peraga "KB" di lintasan secara bergantian. Setelah itu guru memmperjelas manfaat alat peraga kepada masing-masing kelompok dan membegikan soal kepada setiap kelompok sebagai latihan praktek. Setelah setiap kelompok melakukan uji coba menggunakan alat peraga, selanjutnya setiap perwakilan kelompok diminta untuk memperagakan lompatan yang akan digunakan dengan menggunakan alat peraga.

Observasi dan Evaluasi. Hasil observasi dan evaluasi pada siklus I dapat dilihat pada lampiran.

Refleksi. Berdasarkan tindakan yang telah dilakukan dan diamati melalui kegiatan observasi, kegiatan pembelajaran dengan menggunakan alat peraga "KB" ternyata masih memiliki beberapa kekurangan-kekurangan yang ditemukan yaitu: (1) Adanya beberapa kelompok peserta didik yang merasa kecewa dan tidak puas karena tidak diberikan kesempatan untuk menggunakan alat peraga "KB" di lintasan. (2) Masih ada beberapa peserta didik yang tidak terlibat aktif dalam menggunakan alat peraga "KB". (3) Pembentukan kelompok tidak berlangsung secara efektif karena masih ada anggota kelompok yang bermasa bodoh dan acuh terhadap pembentuka kelompok dan adanya anggota kelompok yang mendominasi kegiatan tanpa memberikan kesempatan kepada anggota kelompok yang lainnya. (4) Keterbatasan jumlah alat peraga menghambat proses kegiatan pembelajaran karena setiap peserta didik harus bertukar alat peraga secara bergiliran sehingga ada beberapa peserta didik yang tidak mendapatkan kesempatan untuk menghitung dengan menggunakan alat peraga. (5) Dalam hal pemberian penghargaan secara individu maupun kelompok masih terlihat kurang, padahal terlihat bahwa banyak anak yang membutuhkan penghargaan untuk meningkatkan minat belajar anak.

\section{Siklus II}

Pelaksanaan Tindakan. Berdasarkan hasil observasi dan evaluasi pada siklus I, tindakan pada siklus II tidak terlalu berbeda pada tindakan yang dilakukan pada siklus I hanya ada beberapa kegiatan yang dilakukan untuk perbaikanperbaikan pada siklus I yang dianggap perlu.

Observasi dan Evaluasi. Dari hasil observasi dan evaluasi pada siklus II pelaksanaan tindakan ada beberapa hal yang meningkat terutama dalam hal minat dan semangat belajar anak menggunakan alat peraga "KB". Secara keseluruhan terlihat jelas bahwa dengan menggunakan alat peraga "KB" kemampuan raihan jarak lompatan anak meningkat hal ini terlihat dari kegiatan evaluasi yang dilaksanakan (terlampir).

Refleksi. Berdasarkan hasil pengamatan yang dilakukan, keterbatasan alat peraga "KB" sehingga hanya dilaksanakan secara berkelompok menjadi penghambat dalam keberhasilan anak, sehingga refleksi yang harus dilakukan adalah berupaya untuk melengkapi dan memberikan alat peraga kepada setiap anak untuk digunakan baik di sekolah maupun di rumah masing-masing sehingga anak dapat berlatih sendiri baik pada saat istirahat maupun pada saat ada di rumah masing-masing.

\section{Pembahasan}

Hasil tes dianalisis secara kuantitatif dengan menggunakan analisis deskriptif dan data tentang hasil observasi beserta hasil observasi peserta didik dianalisis secara kualitatif. Berdasarkan hasil analisis deskriptif sebagaimana tercantum dalam lampiran, maka rangkuman statistik skor kemampuan berhitung peserta didik kelas V SDN 11 Durian Sebatang Kecamatan Sukadana Kabupaten Kayong Utara dengan menggunakan alat peraga Kardus Bekas "KB" sebagai berikut:

Tabel 1. Skor Hasil Kemampuan Lompat Jauh Siklus 1

\begin{tabular}{ccc}
\hline No & Statistik & Nilai Statistik \\
\hline 1. & Subjek Penelitian & 26 \\
\hline 2. & Skor Ideal & 100 \\
\hline 3. & Skor Maksimum & 80 \\
\hline 4. & Skor Minimum & 60 \\
\hline 5. & Rentang skor & 20 \\
\hline 6. & Rata-rata & 68,46 \\
\hline \multicolumn{2}{l}{ Sumber $:$ Diolah dari hasil penelitian Apabila }
\end{tabular}

Skor hasil kemampuan berhitung peserta didik dikelompokkan ke dalam lima kategori, oleh sebeb itu diperoleh distribusi frekuensi skor yang dapat ditunjukkan pada tabel distribusi presentase. 
Tabel 2. Distribusi dan Persentase Hasil Kemampuan Berhitung Siklus 1

\begin{tabular}{ccccc}
\hline No & Skor & Kategori & Frekuensi & Persentase \\
\hline 1. & $0-34$ & Sangat Rendah & 0 & 0 \\
\hline 2. & $35-54$ & Rendah & 0 & 0 \\
\hline 3. & $55-64$ & Sedang & 15 & 57,70 \\
\hline 4. & $65-84$ & Tinggi & 11 & 42,30 \\
\hline 5. & $85-100$ & Sangat tinggi & 0 & 0 \\
\hline
\end{tabular}

Sumber : Diolah dari hasil penelitian

Dari tabel 1 dan 2 di atas, maka dapat disimpulkan bahwa hasil kemampuan lompat jauh peserta didik kelas V SDN 11 Durian Sebatang Kecamatan Seponti Kabupaten Kayong Utara setelah dilakukan tindakan dengan menggunakan alat peraga "KB" pada siklus I diperoleh skor rata-

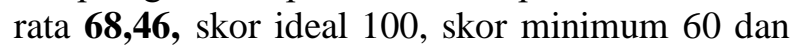
skor maksimum 80.

Pada tabel kategorisasi skor $0-34$ kategori sangat rendah tidak ada peserta didik yang memperoleh kategori tersebut, skor 35-54 kategori rendah juga tidak ada peserta didik yang memperoleh skor tersebut. Untuk skor 55-64 kategori sedang terdapat 15 peserta didik yang mencapai kategori tersebut atau sekitar 57,70 persen, sedangkan untuk skor 65-84 kategori tinggi terdapat 11 orang atau sekitar 42,30 persen dan untuk skor 85-100 kategori sangat tinggi tidak ada peserta didik yang mencapai skor tersebut. Dengan demikian, jika kita kaitkan antara ratarata skor dengan kategori skor, maka kemampuan berhitung peserta didik kelas V SD Inpres Bollangi Kecamatan Seponti Kabupaten Kayong Utara pada siklus I termasuk kategori sedang.

Apabila hasil belajar peserta didik pada siklus I dianalisis, maka persentase ketuntasan belajar peserta didik dengan standar $\mathrm{KKM}=70$ pada siklus I dapat dilihat pada tabel 3 sebagai berikut:

Tabel 3. Deskripsi Ketuntasan Belajar Siklus 2

\begin{tabular}{cccc}
\hline Persentase Skor & Kategori & Frekuensi & Persen \\
\hline $0-69$ & Tidak tuntas & 15 & 57,70 \\
\hline $70-100$ & Tuntas & 11 & 42,30 \\
\hline
\end{tabular}

Sumber : Diolah dari hasil penelitian

Dari tabel 3 di atas, menunjukkan bahwa pada siklus I persentase ketuntasan peserta didik hanya sebesar $42,30 \%$ yaitu sebanyak 11 orang peserta didik dari 26 orang. Sedangkan untuk persentase tidak tuntas terdapat $57,70 \%$ yaitu sebanyak 15 orang peserta didik dari 26 orang. Hal inilah yang kemudian menjadi catatan dan refleksi untuk perbaikan pada siklus II.

Berdasarkan hasil analisis deskriptif sebagaimana tercantum pada lampiran, maka rangkuman statistik skor hasil kemampuan berhitung peserta didik kelas V SDN 11 Durian Sebatang Kecamatan Seponti Kabupaten Kayong Utara sebagai berikut:
Tabel 4. Skor Hasil Kemampuan Berhitung Siklus 2

\begin{tabular}{ccc}
\hline No & Statistik & Nilai Statistik \\
\hline 1. & Subjek Penelitian & 26 \\
\hline 2. & Skor Ideal & 100 \\
\hline 3. & Skor Maksimum & 100 \\
\hline 4. & Skor Minimum & 60 \\
\hline 5. & Rentang skor & 40 \\
\hline 6. & Rata-rata & 80,77 \\
\hline
\end{tabular}

Sumber : Diolah dari hasil penelitian Apabila

Skor hasil kemampuan berhitung peserta didik dikelompokkan ke dalam lima kategori, maka diperoleh distribusi frekuensi skor yang dapat ditunjukkan pada tabel 5 berikut:

Tabel 5. Distribusi dan Persentase Hasil kemampuan Berhitung Siklus 2

\begin{tabular}{llllll}
\hline \multicolumn{1}{c}{ No } & \multicolumn{1}{c}{ Skor } & \multicolumn{1}{c}{ Kategori } & Frekuensi & \multicolumn{1}{c}{ Persentase } \\
\hline 1. & $0-34$ & Sangat Rendah & 0 & 0 \\
\hline 2. & $35-54$ & Rendah & 0 & 0 \\
\hline 3. & $55-64$ & Sedang & 3 & 11,52 \\
\hline 4. & $65-84$ & Tinggi & 19 & 73,10 \\
\hline 5. & $85-100$ & Sangat tinggi & 4 & 15,38 \\
\hline
\end{tabular}


Dari tabel 4 dan 5 di atas, maka dapat disimpulkan bahwa hasil kemampuan lompat jauh peserta didik kelas V SDN 11 Durian Sebatang Kecamatan Seponti Kabupaten Kayong Utara setelah dilakukan tindakan dengan menggunakan alat peraga "KB" pada siklus II diperoleh skor rata-rata 80,77, skor ideal 100, skor minimum 60 dan skor maksimum 100.

Pada tabel kategorisasi skor 0-34 kategori sangat rendah tidak ada peserta didik yang memperoleh kategori tersebut, skor 35-54 kategori rendah juga tidak ada peserta didik yang memperoleh skor tersebut. Untuk skor 55-64 kategori sedang terdapat 3 peserta didik yang mencapai kategori tersebut atau sekitar 11,55 persen, sedangkan untuk skor 65-84 kategori tinggi terdapat 19 orang atau sekitar 73,10 persen dan untuk skor 85-100 kategori sangat tinggi terdapat 4 peserta didik atau sekitar 15,38 persen peserta didikyang mencapai skor tersebut. Dengan demikian, jika kita kaitkan antara rata-rata skor dengan kategori skor, maka kemampuan lompat Jauh peserta didik kelas V SDN 11 Durian Sebatang Kecamatan Seponti Kabupaten Kayong Utara pada siklus II termasuk kategori tinggi.

Tabel 6. Deskripsi Ketuntasan Belajar Siklus 2

\begin{tabular}{cccc}
\hline Persentase Skor & Kategori & Frekuensi & Persen \\
\hline $0-69$ & Tidak tuntas & 3 & 11,52 \\
\hline $70-100$ & Tuntas & 23 & 88,48 \\
\hline
\end{tabular}

Sumber : Diolah dari hasil penelitian

Dari tabel 6 di atas, menunjukkan bahwa pada siklus II persentase ketuntasan peserta didik mencapai $88,48 \%$ yaitu sebanyak 23 orang peserta didik dari 26 orang. Sedangkan untuk persentase tidak tuntas hanya terdapat $11,52 \%$ yaitu sebanyak 3 orang peserta didik dari 26 orang.
Selanjutnya pada tabel 7 memperlihatkan peningkatan kualitas belajar peserta didik dalam hal ini kemampuan lompat jauh penjaskes dengan menggunakan alat peraga "KB" pada siklus I dan siklus 2 .

Tabel 7. Perbandingan Skor Tiap Siklus

\begin{tabular}{rlllllll}
\hline \multirow{2}{*}{ Siklus } & \multicolumn{3}{c}{ Skor perolehan peserta didik } & \multicolumn{2}{c}{ Tuntas } & \multicolumn{2}{c}{ Tidak Tuntas } \\
\cline { 2 - 8 } & $\begin{array}{l}\text { Minimu } \\
\mathrm{m}\end{array}$ & $\begin{array}{l}\text { Maksimu } \\
\mathrm{m}\end{array}$ & Rata-rata & $\begin{array}{l}\text { Frekuen } \\
\text { si }\end{array}$ & Persentase & Frekuensi & $\begin{array}{l}\text { Persenta } \\
\text { se }\end{array}$ \\
\hline Siklus 1 & 60 & 80 & 68,46 & 11 & 42,30 & 15 & 57,70 \\
Siklus 2 & 60 & 100 & 80,77 & 23 & 88,48 & 3 & 11,52 \\
\hline
\end{tabular}

Sumber : Data diolah dari hasil penelitian

Dari tabel 7 di atas menunjukkan bahwa ratarata skor perolehan peserta didik dari siklus I ke siklus 2 terjadi peningkatan sekitar 12,31, sedangkan ketuntasan belajar peserta didik dari siklus I ke siklus 2 peningkatan persentasenya sekitar 46,18\%. Hal ini berarti indikator kinerja yang ada terpenuhi yaitu terjadi peningkatan kemampuan lompat jauh peserta didik kelas $\mathrm{V}$ SDN 11 Durian Sebatang Kecamatan Seponti Kabupaten Kayong Utara semester ganjil tahun pelajaran 2019/2017 dengan menggunakan alat peraga Kardus Bekas "KB".

Hasil Belajar Peserta didik

Hasil belajar peserta didik selama penelitian dapat ditampilkan dalam bentuk grafik baik grafik sk rata-rata maupun grafik persentase ketuntasan belajar yang dapat dilihat pada grafik sebagai berikut:

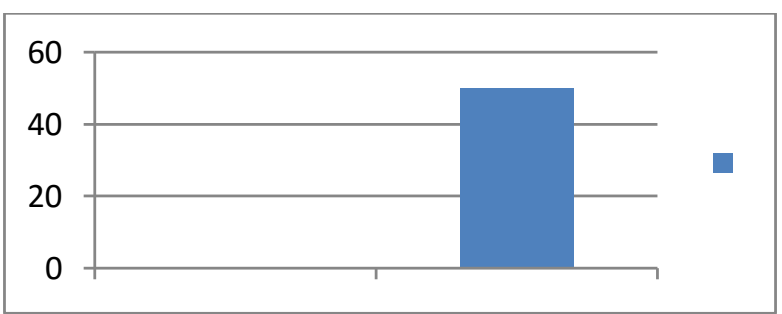

Grafik 1. Skor Rata-rata Siklus 1 dan Siklus 2

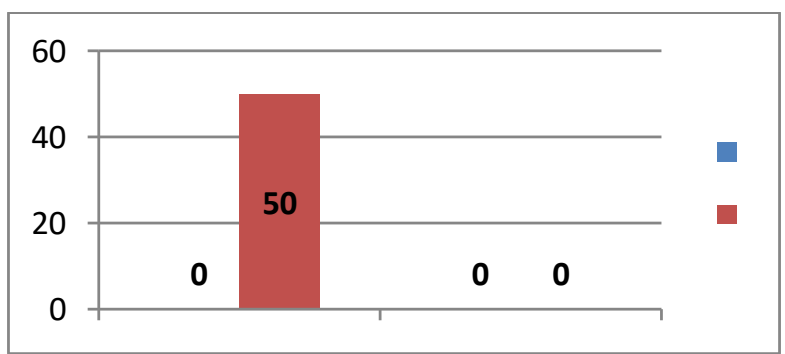

Grafik 2. Persentase Ketuntasan Belajar 
Terjadi peningkatan kemampuan lompat jauh dari siklus I dengan rata-rata $68,46 \%$ meningkat menjadi rata-rata $80,77 \%$ pada siklus 2 disebabkan sistem manajemen kelas yang lebih baik serta manajemen penggunaan alat peraga "KB" yang lebih merata kepada seluruh peserta didik sehingga memungkinkan peserta didik untuk mendapatkan pengalaman langsung (operasional konkret) yang memungkinkan peserta didik untuk melibatkan emosi dan banyak indera sehingga minat belajar peserta didik meningkat.

Terjadi peningkatan persentase ketuntasan belajar dari siklus I sebesar $42,3 \%$ meningkat pada siklus 2 menjadi $88,48 \%$. Hal ini disebabkan karena hasil refleksi pada siklus I yang melihat kekurangan keterbatasan alat peraga "KB" dan sistem manajemen kelas sehingga kekurangan tersebut dapat diperbaiki pada siklus 2. Selain itu, identifikasi peserta didik yang kurang terlibat pada siklus I dapat dilakukan perbaikan pelibatan peserta didik pada siklus 2 .

\section{Analisis Kualitatif Aktivitas Peserta didik Perubahan Aktivitas peserta didik dalam proses pembelajaran}

Berdasarkan hasil observasi/pengamatan yang dilakukan, selain terjadi peningkatan kemampuan berhitung dari siklus 1 ke siklus 2, terjadi pula perubahan sikap peserta didik dalam proses pembelajaran. Perubahan tersebut merupakan data kualitatif yang diperoleh dari lembar observasi (terlampir) yang dicatat pada setiap siklus.

Adapun perubahan-perubahan yang dimaksud adalah: (1) Meningkatkatnya minat belajar peserta didik dari siklus I ke siklus 2 ini menunjukkan bahwa perbaikan sistem manajemen kelas dan penggunaan alat peraga "KB" secara lebih maksimal yang dilakukan hasil refleksi memberikan dampak positif terhadap keinginan dan ketertarikan peserta didik untuk belajar. (2) Perhatian peserta didik pada proses pembelajaran dari siklus 1 ke siklus 2 memperlihatkan adanya peningkatan dengan semakin banyaknya peserta didik yang memperhatikan dan terlibat aktif dalam kegiatan pembelajaran. (3) Meningkatnya angka pertisipasi peserta didik dengan semakin banyaknya peserta didik yang aktif dalam kegiatan pembelajaran yang dilakukan dari siklus 1 ke siklus 2 disebabkan penggunaan alat peraga "KB" secara lebih optimal menjadi bagian penting terhadap peningkatan kemampuan berhitung peserta didik. (2) Semakin banyaknya peserta didik yang terlibat dalam kegiatan presentasi baik secara kelompok maupun individual juga memberikan dampak positif terhadap peningkatan kemampuan lompat jauh peserta didik. (3) Semakin berkurangnya jumlah peserta didik yang melakukan kegiatan yang bukan merupakan kegiatan pembelajaran juga menjadi hal penting yang menjadi pertanda bahwa anak lebih senang dalam kegiatan pembelajaran yang dilakukan dengan menggunakan alat peraga "KB".

\section{Refleksi terhadap pelaksanaan tindakan dengan menggunakan alat peraga "KB" Refleksi pelaksanaan siklus I}

Pada siklus I pembelajaran dengan menggunakan alat peraga "KB" dilakukan dengan pembelajaran secara berkelompok (Cooperative learning) dengan menggunakan metode, demontrasi, penugasan, dan tanya jawab. Pada siklus I masih terlihat beberapa kekurangan termasuk kekurangan dalam hal penggunaan alat peraga ' $\mathrm{KB}$ ' dimana alat peraga yang digunakan masih terbatas sehingga banyak peserta didik yang tidak terlibat aktif dalam kegiatan pembelajaran. Selain jumlah alat peraga yang terbatas, pengelolaan kelas dan pembagian kelompok juga menjadi penyebab banyaknya peserta didik yang tidak serius dalam mengikuti kegiatan pembelajaran. Ketidak aktifan beberapa peserta didik dalam kelompok disebabkan karena kurangnya alat peraga yang digunakan mengakibatkan peserta didik tersebut memiliki hasil belajar yang rendah pada siklus I.

\section{Refleksi siklus II}

Setelah merefleksi hasil pelaksanaan siklus I, diperoleh beberapa masukan dan perbaikan berdasarkan kekurangan-kekurangan yang ada pada siklus I sehingga pada pelaksanaan siklus II terjadi peningkatan baik secara kuantitatif dalam bentuk hasil belajar maupun secara kualitatif dalam bentuk aktivitas peserta didik. Pemberian penguatan dan motivasi belajar serta dorongan untuk lebih menyukai pelajaran matematika yang selama ini dianggap menyeramkan bagi peserta didik dirasa perlu sebagai hasil refleksi pada siklus II ini sehingga dengan adanya minat dan semangat belajar yang tinggi terhadap pelajaran matematika diharapkan dapat memberikan kepercayaan diri bagi peserta didik untuk lebih menguasai konsep-konsep dan Praktek-praktek Penjaskes yang lebih kompleks. Selain itu penggunaan alat peraga untuk setiap konsep khususnya dalam pelajaran matematika sangat diperlukan dengan melihat keberhasilan penggunaan alat peraga ' $\mathrm{KB}$ ' ini terhadap peningkatan kemampuan berhitung peserta didik. Dengan menggunakan alat peraga minat, perhatian, partisipasi dan presentasi peserta didik lebih meningkat serta pembelajaran benar-benar berpusat pada anak (Students Cetered).

Secara umum dapat dikatakan bahwa dengan menggunakan alat peraga Kardus Bekas (KB) kemampuan peserta didik secara kuantitatif dalam bentuk kemampuan lompat jauh dan secara 
kualitatif dalam bentuk minat, perhatian, partisipasi dan presentasi peserta didik lebih meningkat.

\section{SIMPULAN DAN SARAN \\ Simpulan}

Dari hasil penelitian tindakan kelas yang dilaksanakan selama dua siklus, maka dapat disimpulkan: (1) Rata-rata skor perolehan kemampuan lompat jauh peserta didik dari siklus I ke siklus 2 terjadi peningkatan. Selain skor ratarata ketuntasan belajar peserta didik dari siklus I ke siklus II juga terjadi peningkatan. Hal ini disebabkan karena penggunaan alat peraga Kardus Bekas (KB) dengan perbaikan manajemen kelas yang lebih baik yang dilakukan secara berkelompok. (2) Terjadi peningkatan kualitas pembelajaran peserta didik yang ditandai dengan peningkatan keaktifan peserta didik baik dalam bentuk minat belajar, perhatian terhadap pelajaran, angka partisipasi, dan presentasi peserta didik dalam kegiatan pembelajaran Penjaskes dengan menggunakan alat peraga Kardus Bekas (KB).

\section{Saran}

Dari hasil yang diperoleh dalam penelitian ini, maka ada beberapa saran yang diajukan yaitu: (1) Penggunaan alat peraga Kardus Bekas (KB) untuk meningkatkan kemampuan lompat jauh peserta didik layak dipertimbangkan untuk digunakan bagi semua pihak. (2) Penggunaan alat peraga Kardus Bekas (KB) disarankan untuk digunakan pada jenjang yang lebih dini misalnya pada TK/PAUD. (2) Bagi guru dan praktisi pendidikan untuk selalu mengasah kreatifitas sehingga mampu menciptakan alat peraga yang tepat guna. (3) Pihak pemerintah hendaknya memberikan penghargaan yang lebih kepada guru-guru yang sungguh-sungguh berbuat yang terbaik untuk kemajuan pendidikan.

\section{DAFTAR PUSTAKA}

Abdurrahman, Mulyono. 2003. Pendidikan Bagi Anak Berkesulitan Belajar. Jakarta: PT. Rineka Cipta.

Arikunto, Suharsimi. 2006. Prosedur Penelitian. Jakarta: PT Rineka Cipta.
Arsyad, Azhar. 2004. Media Pembelajaran.Jakarta: Rajawali Pers

DePotter, Bobby Dkk. 1999. Quantum Teaching, mempraktekkan Quantyum learning dalam ruang-ruang kelas. Penerjemah Ary Nilandari. Bandung: Mizan Pustaka.

Daruma, razak. 2003. Pengunaan Tes Psikologi. Makassar : FIP UNM.

Daruma, Razak. 2005. Perkembangan Peserta Didik. Makassar : FIP UNM.

Dimyati. 1994. Belajar Dan pembelajaran. Jakarta : DEPDIKNAS.

Djamarah. 1994. Prestasi Belajar dan Kompetensi Guru. Surabaya: Usaha Nasional.

Lutan, Rusli. 2000. Filsafah Olahraga. Jakarta : DEPDIKNAS.

Muhammadiah. 2005. Perencanaan Pengajaran Pendidikan Jasmani Dan Kesehatan. Makassar : FIP UNM.

Mutiah, Diana. 2010. Psikologi Bermain Anak Usia Dini. Jakarta: Kencana

Silberman, Melvin L. 2006. Active Learning, 101 cara belajar peserta didik aktif. Penerjemah Raisul Muttaqien. Bandung: Nusamedia.

Solthan, Ibrahim. 2006. Menuju Pendidikan Masa Depan. Bantaeng: LP3M Intim.

Slameto. 1995. Belajar dan Faktor yang mempengaruhi. Jakarta: Rineka Cipta.

Sri Wardhani. 2008. Pembelajaran Penggunaan Alat Ukur Panjang. Diktat. Departemen Pendidikan Nasional.

Sudjana Nana. 1989. Cara Belajar Peserta didik Aktif dan Proses Belajar. Bandung: Sinar baru.

Sudjana, Nana dan Ahmad Rivai. 2001. Media Pengajaran. Bandung: Sinar Baru Algensindo.

Sukintana. 2004. Teori Pendidikan Jasmani. Bandung : Nuansa.

Sumantri, Mulyani dan Johar Permana. 1999. Strategi Belajar mengajar. Jakarta: DepDikBud

Tiro, Arif Muhammad. 2000. Dasar-dasar statistika. Makassar: MSU Press (Makassar State University Press).

Wahjoedi. 2001. Landasan Evaluasi Pendidikan Jasmani. Jakarta : PT. Rajagrafindo Persada. 